\title{
PENDAMPINGAN PEMBUATAN PAKAN DARI SAMPAH ORGANIK SECARA FERMENTASI KEPADA PETERNAK BEBEK DI KOTA BATU
}

\author{
Damat Damat ${ }^{1}$, Lili Zalizar'2), Vritta Amroini ${ }^{1)}$ \\ 1)Teknologi Pangan, FPP, Universitas Muhammadiyah Malang, Malang, Jawa Timur, Indonesia \\ 2)Peternakan, FPP, Universitas Muhammadiyah Malang, Malang, Jawa Timur, Indonesia \\ Corresponding author: Damat Damat \\ E-mail : damatumm@gmail.com
}

Diterima 25 September 2020, Direvisi 12 Oktober 2020, Disetujui 12 Oktober 2020

\begin{abstract}
ABSTRAK
Tempat pembuangan akhir (TPA) di Desa Tlekung, Kota Batu, telah memberikan manfaat bagi para peternak bebek di Desa tersebut. Masyarakat setempat dapat memanfaatkan sampah organik sebagai pakan bebek. Akan tetapi penggunaan sampah tersebut untuk pakan bebek menimbulkan masalah, yaitu timbulnya cemaran bau yang berasal dari sampah yang belum terfermentasi dengan sempurna, dan rata-rata tingkat kematian bebek cukup tinggi. Pengabdian kepada masyarakat ini dilakukan dengan tujuan untuk melakukan transfer teknologi fermentasi sampah organik sebagai pakan bebek. Kegiatan ini dilakukan dalam beberapa tahap, yaitu (i) survei lapangan, (ii) penyampaian materi teori disampaikan secara klasikal , (iii) penyampaian materi keterampilan dalam bentuk praktik/ demonstrasi pembuatan pakan organik secara fermentasi dan (iv) pendampingan kepada para peternak serta (v) monitoring dan evaluasi kegiatan. Hasil yang diperoleh sangat menggembirakan dan memberikan kepuasan tersendiri bagi peternak. Feses bebek yang diberi pakan hasil proses fermentasi sudah tidak bebau seperti semula, bulu bebek dapat tumbuh dengan baik, dan bebek yang dihasilkan tampak lebih gemuk dan lebih sehat dan memiliki pertambahan berat badan lebih baik dibandingkan dengan yang diberi pakan yang tidak diferementasi. Disamping itu, penggunaan pakan fermentasi dari sampah organik diketahui dapat menghemat biaya pakan sampai sebesar $60 \%$, sehingga keuntungan peternak menjadi meningkat.
\end{abstract}

Kata kunci: tempat pembuangan akhir; sampah organik; pakan organik.

\begin{abstract}
The landfill in Tlekung Village, Batu City, has provided benefits for duck farmers in the village. Local people can use organic waste as duck feed. However, the use of organic waste as duck feed causes some problems, that is odor contaminant from unfinished fermentation, also high average rate duck mortality. This community service program is carried out to transferring organic waste fermentation technology knowledge in feed duck production. Program consist of (i) field survey, (ii) classical theory sharing, (iii) skill sharing by practice/ demonstration of organic duck fermented feed production, (iv) assistance of duck farmers, and (v) monitoring and evaluation of program. The results obtained are very encouraging and give satisfaction to farmers. The duck feces which fed with fermentation organic production have no smell like before, duck feathers can grow well, also duck look healthier and have better weigh gain than duck which fed with unfermented fed. In addition, the use of fermented feed from organic waste is known to save feed cost up to $60 \%$. So, it is increasing farmer's profit.
\end{abstract}

Keywords: organic waste; duck feed; fermented feed.

\section{PENDAHULUAN}

Sampah di Tempat Pembuangan Akhir (TPA) merupakan salah satu sumber pakan ternak yang cukup potensial. Akan tetapi upaya untuk memanfaatkan sampah dari TPA sebagai pakan bebek, ternyata menimbulkan persoalan baru, yaitu munculnya bau yang sangat tidak sedap, sehingga menimbulkan pencemaran lingkungan. Bau yang keluar dari sampah tersebut merupakan indikasi bahwa sampah tersebut masih mengalami proses fermentasi dan menghasilkan gas metan $\left(\mathrm{CH}_{4}\right)$ (Achinas,
Achinas, \& Euverink, 2017). Sampah perlu difermentasi terlebih dulu dengan maksud agar terjadi peningkatan komponen gizi dan untuk meningkatkan kecernaan dari sampah tersebut. Beberapa jenis mikroba, terutama dari jenis lignoselulitik diketahui memiliki kemampuan untuk mendegradasi serat (Latif, Harun, Sajab, Markom, \& Jahim, 2018). Proses fermentasi yang dilakukan dengan cara yang tepat dan dengan menggunakan inokulan tepat dapat menghasilkan produk bermutu (Pamungkas, 2011). Sampah yang tidak terfermentasi 
dengan sempurna dapat menyebabkan terjadinya gejala aspergilosis yang dapat berakibat kematian pada hewan yang mengkonsumsinya (Utomo, Herawat, \& Prawirodigdo, 2010).

Upaya untuk memanfaatkan sampah dari TPA untuk pakan bebek sudah mulai menimbulkan persoalan baru dan sudah mulai banyak dikeluhkan oleh warga sekitar kandang. Oleh karena itu, persoalan tersebut harus segera diatasi, bila tidak segera diatasi berpotensi menimbulkan konflik sosial di masyarakat, mengingat budidaya ternak bebek tersebut dilakukan di perkampungan yang padat penduduk.

Lokasi ternak bebek yang terdapat di Desa Tlekung sesungguhnya belum memenuhi syarat lokasi ternak yang baik. Lokasi yang baik harus jauh dari pemukiman penduduk, terdapat sumber air yang memenuhi persyaratan baku mutu air untuk usaha ternak (Putra, Efendi, \& Brata, 2018).

Selain persoalan cemaran lingkungan sebagaimana tersebut di atas, berdasarkan hasil kunjungan lapang dan diskusi dengan anggota Tani "SUMBER URIP" dan Kelompok Tani "HARAPAN JAYA" juga diperoleh berbagai persoalan. Hal sangat wajar, mengingat usaha beternak bebek merupakan usaha baru rintisan. Beberapa permasalahan yang dihadapi antara lain adalah sebagai berikut: (i) Rata-rata tingkat kematian yang cukup tinggi $(10-15 \%)$. (ii) Teknik pemberian pakan yang belum optimal dan seadanya, sehingga laju pertambahan bobot bebek juga belum optimal. (iii) Belum ada treatment apapun juga terhadap sampah yang diperoleh dari TPA, kecuali pemisahan dari sampah an organik. Hal ini selain dapat meningkatkan cemaran lingkungan, juga dapat menjadi pembawa berbagai jenis penyakit, baik bagi bebek, peternak maupun bagi konsumen. (iv) Kotoran ternak belum diolah menjadi pupuk organik. (v) Manajemen pembukuan yang belum tertata dengan baik.

Lima permasalahan tersebut kemudian dirumuskan lebih lanjut berdasarkan hasil kesepakatan antara Tim Pengabdi UMM bersama mitra untuk mendapatkan perioritas yang harus ditangani sebagai berikut: (i) Perlu adanya pendampingan berkelanjutan dalam mengembangkan usaha bebek di kelompok tani "SUMBER URIP" dan Kelompok Tani "HARAPAN JAYA". (ii) Perlu penguatan kelembagaan kelompok agar lebih efisien dalam menjalankan usahanya. (iii) Perlu paket teknologi ternak bebek terutama teknologi fermentasi sampah dari TPA sebelum digunakan sebagai pakan bebek. (iv) Perlu bimbingan manajemen mulai dari manajemen usaha budidaya, penguatan kelembagaan, pemasaran dan pasca panen. (v) Pencegahan penyakit dan menekan kematian bebek.

Permasalahan tersebut di atas terjadi sebagai akibat masih cukup rendahnya tingkat pendidikan dimana sebagian besar rata-rata peternak bebek di Desa Tlekung berpendidikan SD $(12,5 \%)$, SLTP $(37,5 \%)$ dan SLTA $(37,5 \%)$, sedangkan yang berpendidikan tinggi tidak ada dan yang tidak lulus SD Permasalahan tersebut di atas terjadi sebagai akibat masih cukup rendahnya tingkat pendidikan dimana sebagian besar rata-rata peternak bebek di Desa Tlekung berpendidikan SD (12,5\%), SLTP $(37,5 \%)$ dan SLTA $(37,5 \%)$, sedangkan yang berpendidikan tinggi tidak ada dan yang tidak lulus SD terdapat $12,5 \%$. Rendahnya tingkat pendidikan akan berdampak pada rendahnya pengetahuan dan keterampilan para peternak.

Permasalahan yang dihadapi Kelompk Tani "SUMBER URIP" dan Kelompok Tani "HARAPAN JAYA" merupakan permasalahan mendasar dari kegiatan pemberdayaan ekonomi masyarakat. Karena itu sebagai upaya untuk membantu para peternak bebek menyelesaikan problem yang mereka hadapi, maka diperlukan pendampingan. Melalui kegiatan pengabdian ini diharapkan mampu menjembatani terealisasinya kelembagaan kelompok yang kuat dan solid serta mampu saling membantu antar mereka. Program pendampingan ini diharapkan dapat dilakukan transfer teknologi tepat guna (TTG) dalam usaha budidaya bebek, yang pada gilirannya dapat meningkatkan produktivitas bebek dan pendapatan para peternak.

Berlandaskan pada uraian di atas, maka yang menjadi prioritas kegiatan pengabdian ini adalah meningkatkan skill masyarakat (Mukmin \& Lisnanti, 2019), terutama yang berkaitan dengan teknologi fermentasi sampah menjadi pakan bebek, sehingga dapat mengurangi cemaran lingkungan dan mengurangi potensi timbulnya berbagai penyakit bawaan. Selain itu juga perlu dilakukan pembinaan dan pendampingan secara berkelanjutan untuk mengembangkan usahanya mulai dari manajemen usaha, mengelola organisasi, pemasaran dan penguatan jejaring bisnis bebek pedaging. Semua ini dapat terwujud dengan melalui kegiatan pembinaan dan pendampingan berkelanjutan.

\section{METODE \\ Waktu dan Tempat}

Kegiatan ini dilaksanakan di Desa Tlekung, Kecamatan Junrejo, Kota Batau, Jawa Timur. Waktu pelaksanaan bulan SeptemberOktober 2019.

\section{Prosedur Pelasanaan}


Berdasarkan permasalahan yang telah dikemukakan di atas, maka penerapan IPTEKS bagi masyarakat terutama peternak bebek sangat diperlukan. Hal ini dikarenakan peternak bebek di Desa Tlekung, Kota Batu, Jawa Timur belum memiliki keterampilan yang memadai untuk menunjang dalam usaha ternak bebek. Untuk mengembangkan usaha ternak bebek ini,maka perlu pendidikan kecakapann hidup (life Skills) melalui pendekatan yang berbasis pada kebutuhan riel masyarakat luas (broad based education). Mitra pada program ini adalah kelompok "SUMBER URIP" dan Kelompok Tani "HARAPAN JAYA", dengan total anggota mencapai 60 orang peternak. Pelaksanaan proses pendi-dikan perlu tetap memperhatikan keragaman keadaan dan atau kebutuhan daerah setempat serta kebutuhan pendidikan dapat direalisasikan. Merujuk dari permasalahan di atas diperlukan pendidikan non formal yang mampu menjadi pemacu untuk bersedia secara sadar meningkatkan kemampuan dan keterampilan hidup sehari-hari sebagai modal berharga untuk kehidupan dimasa sekarang dan dimasa yang akan datang yang lebih baik.

Adapun kecakapan hidup yang akan diberikan kepada peternak bebek adalah:

1). Kecakapan Pribadi (Personal Skill) meliputi kecakapan untuk mengenali diri sendiri, berpikir rasional, serta kecakapan untuk dapat tampil dengan kepercayaan diri yang baik.

2). Kecakapan Sosial (Social Skill) meliputi kecakapan berkomunikasi, kerjasama, betenggang rasa, kepedulian dan tanggungjawab sosial dalam kehidupan bermasyarakat.

3). Kecakapan Akademik (Academic Skill) meliputi kecakapan untuk memecahkan poblem yang dihadapi melalui proses berpikir kritis, analitis dan sistimatis. Dengan kecakapan akademik ini, maka peternak akan memiliki kemampuan meneliti, mengeksplorasi, melakukan inovasi dan berkreasi melalui pendekatan ilmiah. Dengan memiliki kecakapan akademik, maka para peternak diharapkan mempunyai keterampilan untuk memanfaat-kan hasil-hasil teknologi untuk mendukung usahanya.

4). Kecakapan Vokasional (Vocational Skill), meliputi kecakapan yang berkaitan dengan bidang keterampilan profesional tertentu dalam dunia usaha dan industri baik dipergunakan untuk bekerja pada dunia usaha/dunia industri mapun usaha mandiri.

Untuk menyelesaikan persoalan yang kelompok "SUMBER URIP" dan Kelompok Tani
"HARAPAN JAYA" maka dalam penerapan IPTEKS bagi masyarakat dapat dilakukan langkah-langkah pembelajaran dalam bentuk pelatihan secara intensif dan pendapingan berkelanjutan bagi peternak bebek, dengan ketentuan:

1). Penyampaian materi teori disampaikan secara klasikal

2). Penyampaian materi keterampilan dalam bentuk praktik/demonstrasi

3). Komposisi penyajian Teori dan Praktek masing-masing : $30 \%: 70 \%$

4). Proses pembelajaran didukung dengan media belajar dan modul yang memadai dan atau kunjungan kerja lapangan ke beberapa tempat usaha yang telah berkembang.

Pelaksanaan penerapan IPTEKS

melalui pelatihan peningkatkan kemampuan keterampilan teknik beternak bebek meliputi:

a. Keterampilan teknik fermentasi sampah menjadi bahan pakan bebek.

b. Keterampilan menyusun pakan yang berkualitas untuk bebek dengan memanfaatkan bahan-bahan yang banyak tersedia di sekitar lokasi (bekatul, dan eceng gondok) sehingga harga pakan tambahan menjadi murah.

c. Keterampilan membuat Compled Feed.

d. Keterampilan mengolah sampah ternak menjadi pupuk organik

e. Pengetahuan pencegahan penyakit melalui sanitasi kandang dan ternak yang sehat serta penanganan bebek yang terkena penyakit.

Materi yang diberikan dalam pembelajaran penerapan IPTEKS usaha ternak bebek meliputi: Materi umum berupa manajemen usaha, kewirausahaan, pemasaran, jaringan bisnis, sedangkan materi khusus meliputi pengelolaan dan pengembangan wirausaha dalam hal budidaya bebek, pengolahan pakan, penanganan dan pengolahan sampah

\section{HASIL DAN PEMBAHASAN}

Beberapa kegiatan pengabdian yang telah dilakukan antara lain adalah koordinasi dengan peternak, pemberian tong plastik untuk proses fermentasi dan identifikasi jenis sampah organik yang dipergunakan untuk bahan pakan ternak bebek. Pemberian tong plastic sudah diberikan kepada beberapa peternak. Masingmasing peternak tersebut juga diberikan starter untuk memfermentasi sampah.

Hasil kunjungan ke lapangan diketahui bahwa sampah organik yang selama ini banyak digunakan oleh para peternak bebek hampir $100 \%$ berasal dari sampah yang berasal dari TPA (Tempat Pembuangan Akhir) (Gambar 1). 
Pemberian pakan dari sampah ini biasanya diberikan pada ternak bebek pada fase finisher, yaitu pada bebek yang berumur 16 hari sampai panen, umur 45 sampai 60 hari dari DOD. Bebek pada saat berumur 1-15 hari pada umumnya diberi pakan BR-1.

Beberapa persoalan yang terjadi di lapangan adalah (i) pada umumnya sampah yang berasal organik yang digunakan sebagai pakan bebek (Gambar 2) hanya difermentasi secara alami, tidak ada penambahan starter. Kondisi ini sangat mungkin proses fermentasi tidak maksimal, sehingga sangat mungkin beberapa komponen dan senyawa kimia berbahaya yang terbawa di dalam sampah tersebut akan dimakan oleh ternak dan tidak menutup kemungkinan akan terasup oleh mereka yang mengkonsumsi daging bebek tersebut. (2) Bau yang ditimbulkan sangat tajam, sehingga cukup mengganggu kesehatan lingkungan. Bau ini berasal dari proses fermentasi sampah yang belim sempurna dan berasal dari air sampah cucian kotoran dan kandang bebek.

Untuk mengelminir persoalan tersebut, selain memperbaiki proses fermentasi juga dilakukan pemanfaatan sampah padat dari bebek tersebut untuk biogas. (3) Saat ini permintaan sampah organik dari TPA untuk pakan bebek cukup tinggi, sehingga pada harihari tertentu sudah tidak mencukupi untuk memenuhi permintaan pakan peternak bebek di Desa Tlekung. Beberapa peternak seringkali harus mencari sumber pakan tersebut di TPA lainnya. Untuk mengatasi persoalan tersebut maka perlu dicari sumber pakan lain yang cukup potensial dikembangkan dan dengan cara yang sangat mudah. Sumber pakan dimaksud adalah eceng gondok.

Upaya untuk memanfaatkan eceng gondok masih dihadapkan pada kendala tingginya kandungan lignin dan kandungan serat yang cukup tinggi (Wilda \& Pandebesie, 2015), sehingga bila diberikan secara langsung ke bebek, maka konversi energy yang diperoleh sangat rendah. Untuk meningkatkan nilai eceng gondok dapat dilakukan dengan memfermentasi bahan tersebut. Mikroba proteolitik dan selulotik diketahui sangat efektif untuk memfermentasi eceng gondok (Sukaryo \& Purwaningrum, 2016). Mikroba proteolitik diketahui memiliki kemampuan untuk memproduksi enzim protease yang dapat mendegradasi protein menjadi asam-asam amino. Enzim selulase memiliki kemampuan untuk mendegradasi senyawa selulosa menjadi senyawa mono, di dan oligosakarida yang dapat dimanfaatkan menjadi sumber karbon, sehingga mikroba dapat berkembang biak dengan baik. Berdasarkan hasil pengujian diketahui bahwa telah terjadi peningkatan kadar protein eceng gondok yang difermentasi (Irawati, Purnamasari, \& Arsyad, 2019).

Pada proses fermentasi eceng gondok, peningkatan protein yang dikarenakan oleh enzim dalam mikroba yang memiliki kemampuan untuk mendegradasi molekul gula menjadi komponen sederhana yang bisa dimanfatkan untuk perkembangan dan pertumbuhan koloni mikroba yang terdapat di dalam sampah tersebut (Ratnaningtyas, Bahrun, Hidayah, \& Herliana, 2019; Zuliyan, Agustono, \& Satyantini, 2019). Peningkatan kadar protein eceng gondok yang telah mengalami proses fermentasi merupakan indikasi bahwa di dalam starter tersebut terdapat mikroba proteolitik. Salah satu mikroba proteolitik yang terdapat dalam starter tersebut adalah Lactobacillus sp. Mikroba ini memiliki kemampuan untuk menghasilkan enzim protease yang dapat mendegradasi protein menjadi polipeptida, selanjutnya menjadi peptida sederhana, kemudian peptide tersebut akan dirombak menjadi asam-asam amino (Fitrihidajati, Herlina; Ratnasari Evie; Isnawati, Soeparno, 2015). Asam-asam amino inilah yang akan dimanfaatkan oleh mikroba untuk memperbanyak diri. Peningkatan jumlah koloni mikroba selama proses fermentasi secara tidak langsung dapat meningkatkan kadar protein karena mikroba merupakan sumber protein sel tunggal (Widanti, 2012).

Pada saat proses fermentasi dibutuhkan karbon dan nitrogen yang akan dipergunakan untuk perkembangnya sel-sel mikroba (Zuliyan et al., 2019). Penambahan tetes tebu pada proses fermentasi eceng gondok dapat menyediakan sumber energi untuk mikroba untuk bekerja pada pakan yang banyak mengandung serat kasar seperti selulosa, lignoselulosa serta hemiselulosa. Serat dikalisifikasikan menjadi dua, yaitu serat larut dan serat tidak larut (Damat et al., 2019).

Tetes tebu yang mengandung karbohidrat dan mineral yang tinggi mampu menstimulir pertumbuhan mikroba sehingga kandungan protein meningkat (Widya Paramita L, Agustono, 2019). Pertumbuhan dan perkembangan dari mikrobia sangat ditentukan oleh ketersiediaan karbon. Apabila ketersediaan karbon memadai, maka mikrobia dapat umbuh dan bekembang dengan baik, akan tetapi apabila keersediaannya terbatas, maka pertumbuhan dan perkembangan mikroba akan terhambat. Jai ketersediaan karbon bisa menjadi faktr penentu pertumbuhan mikroba (Nursanti, 2017).

Pada proses fermentasi, mikroba proteolitik dapat memproduksi enzim protease. Enzim ini diketahui memiliki kemampuan untuk 
merombak molekul protein menjadi polipeptida, dan kemudian didegradasi lebih lanjut menjadi molekul peptide sederhana (Wikandari, Suparmo, Marsono, \& Rahayu, 2012). Peptide sederhana tersebut kemudian didegradasi menjadi asam amino. Asam amino ini selanjutnya digunakan oleh mikroba proteolitik maupun selulolitik untuk memperbanyak diri, sehingga koloni mikroba akan meningkat pula. Dengan demikian selama proses fermentasi berlangung, maka jumlah koloni mikroba juga akan terus meningkat, kadar protein juga meningkat. Hal ini dikarenakan mikroba juga merupakan merupakan sumber protein sel tunggal (Maryana, Anam, \& Nugrahani, 2016). Peningkatan kandungan protein dapat menyebabkan kandungan serat dalam pakan akan menurun. Kondisi ini dapat mengakibatkan aktifitas mikroba selulotik semakin meningkat, sehingga proses degradasi selulosa oleh enzim selulase yang dihasilkan oleh mikroba selulotik semakin optimal.

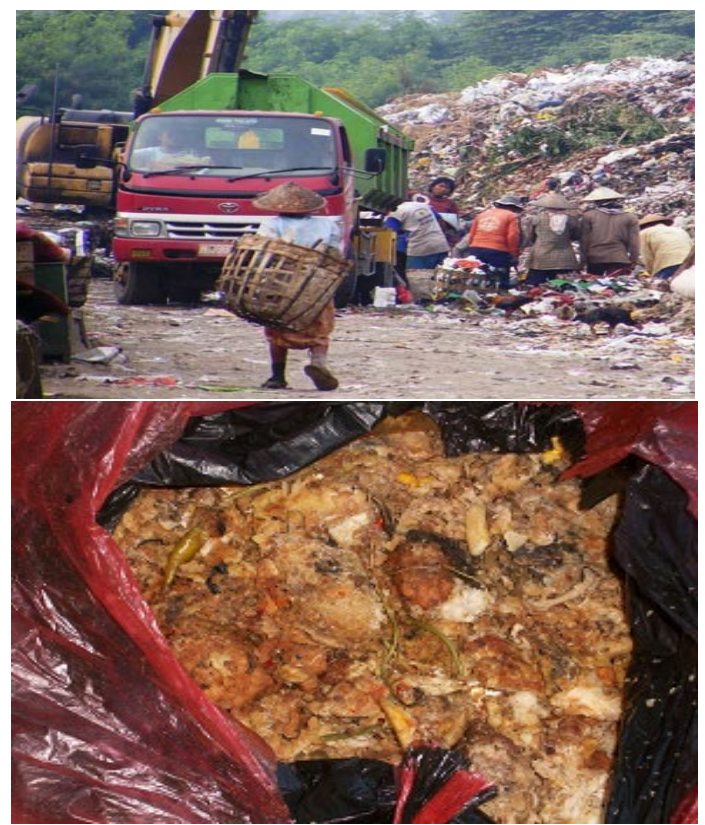

Gambar 1. TPA di Desa Tlekung dan sampah organik dari TPA tersebut

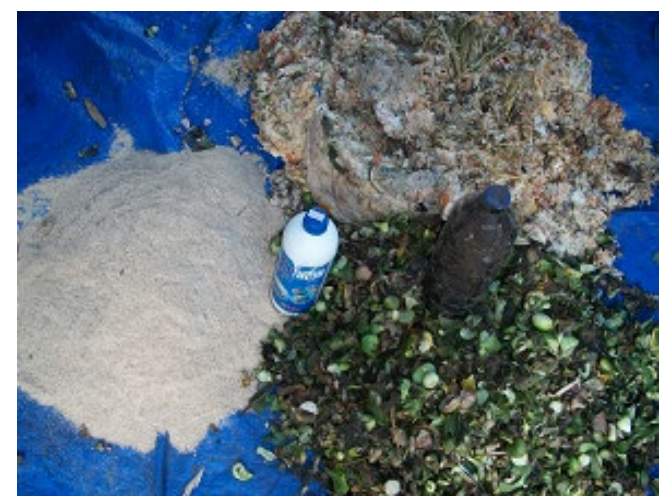

Gambar 2. Bahan pakan bebek dari sampah organik, eceng gondok, dan bekatul sebelum difermentasi

Pakan hasil fermentasi yang diketahui juga dapat menekan biaya pakan. Berdasarkan hasil perhitungan secara ekonomis, diketahui bahwa pemberian pakan hasil fermentasi ini dapat menghemat biaya pakan hingga mencapai $60 \%$. Hasil yang diperoleh sangat menggembirakan. Feses bebek yang diberi pakan hasil proses fermentasi tidak bebau, bulu bebek dapat tumbuh dan berkembang dengan baik, dan bebek yang dihasilkan tampak lebih sehat (Gambar 4) dan memiliki performance yang lebih baik dibandingkan dengan yang diberi pakan buka hasil fermentasi (Gambar 3). Di samping itu, penggunaan pakan fermentasi dengan memanfaatkan eceng gondok diketahui dapat menghemat biaya pakan sampai $60 \%$, sehingga keuntungan peternak meningkat.

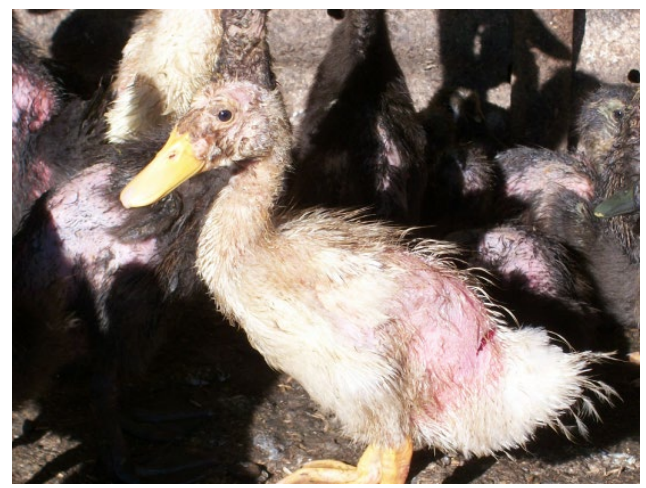

Gambar 3. Performance bebek yang diberi pakan sampah TPA tanpa proses fermentasi

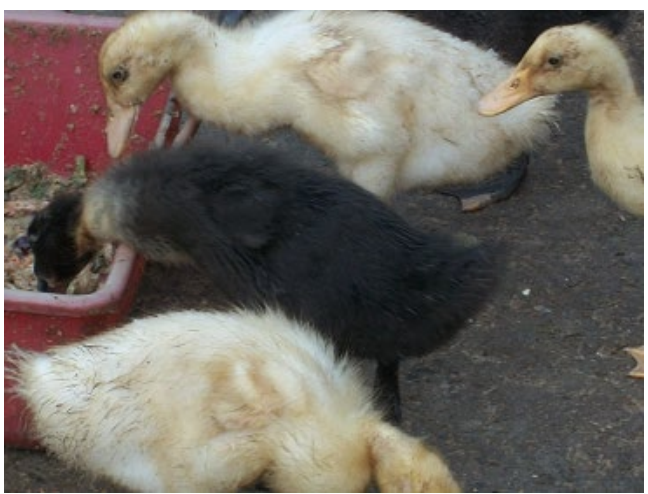

Gambar 4. Performance bebek yang diberi pakan hasil proses fermentasi

\section{SIMPULAN}

Proses fermentasi sampah organik sebagai pakan bebek terbukti dapat memberikan keuntungan. Feses yang dikeluarkan oleh bebek yang diberi pakan hasil proses fermentasi sudah tidak bebau seperti semula, bulu bebek dapat tumbuh dengan baik, 
dan bebek yang dihasilkan tampak lebih sehat dan memiliki performance yang lebih baik dibandingkan dengan yang diberi pakan bukan hasil fermentasi. Disamping itu, penggunaan pakan fermentasi dengan memanfaatkan eceng gondok diketahui dapat menghemat biaya pakan sampai $60 \%$, sehingga keuntungan peternak menjadi meningkat.

\section{UCAPAN TERIMA KASIH}

Ucapan terima kasih disampaikan kepada Bapak Direktur DP2M Ditjen DIKTI yang telah memberikan bantuan pendanaan melalui skim IBM.

\section{DAFTAR RUJUKAN}

Achinas, S., Achinas, V., \& Euverink, G. J. W. (2017). A Technological Overview of Biogas Production from Biowaste. Engineering.

https://doi.org/10.1016/J.ENG.2017.03. 002

Damat, D., Anggriani, R., Setyobudi, R. H., \& Soni, P. (2019). Dietary fiber and antioxidant activity of gluten-free cookies with coffee cherry flour addition. Coffee Science. https://doi.org/10.25186/cs.v14i4.1625

Fitrihidajati, Herlina; Ratnasari Evie; Isnawati, Soeparno, G. (2015). Kualitas Hasil Fermentasi Pada Pembuatan Pakan Ternak Ruminansia Berbahan Baku Eceng Gondok (Eichornia crassipes). Biosaintifika: Journal of Biology \& Biology Education, 7(1), 62-67. https://doi.org/10.15294/biosaintifika.v7 i1.3540

Irawati, E., Purnamasari, E., \& Arsyad, F. (2019). KUALITAS FISIK DAN NUTRISI ECENG GONDOK (Eichornia crassipes) DENGAN LAMA FERMENTASI YANG BERBEDA. JURNAL PETERNAKAN. https://doi.org/10.24014/jupet.v16i1.36 79

Latif, A. A., Harun, S., Sajab, M. S., Markom, M., \& Jahim, J. M. (2018). Ammonia-based pretreatment for ligno-cellulosic biomass conversion - an overview. Journal of Engineering Science and Technology.

Maryana, L., Anam, S., \& Nugrahani, A. W. (2016). PRODUKSI PROTEIN SEL TUNGGAL DARI KULTUR Rhizopus oryzae DENGAN MEDIUM LIMBAH CAIR TAHU. Jurnal Farmasi Galenika (Galenika Journal of Pharmacy) (eJournal).

https://doi.org/10.22487/j24428744.20

16.v2.i2.5987
Mukmin, A., \& Lisnanti, E. F. (2019). Pendampingan Pengembangan Kapasitas Usaha Berbasis Klaster Peternak Sapi Kabupaten Magetan. Cendekia: Jurnal Pengabdian Masyarakat. https://doi.org/10.32503/cendekia.v1i1. 409

Nursanti, I. (2017). TEKNOLOGI PRODUKSI DAN APLIKASI MIKROBA PELARUT HARA SEBAGAI PUPUK HAYATI. Jurnal Media Pertanian. https://doi.org/10.33087/jagro.v2i1.24

Pamungkas, W. (2011). TEKNOLOGI FERMENTASI, ALTERNATIF SOLUSI DALAM UPAYA PEMANFAATAN BAHAN PAKAN LOKAL. Media Akuakultur.

https://doi.org/10.15578/ma.6.1.2011.4 3-48

Putra, P. D., Efendi, H., \& Brata, W. W. W. (2018). Peningkatan Pendapatan Peternak Bebek Melalui Pelatihan Pakan Ternak Dan Kewirausahaan. JPPM (Jurnal Pengabdian Dan Pemberdayaan Masyarakat). https://doi.org/10.30595/jppm.v2i1.171 3

Ratnaningtyas, N. I., Bahrun, B., Hidayah, R. N., \& Herliana, O. (2019). INTRODUKSI PEMANFAATAN ECENG GONDOK SEBAGAI PAKAN TERNAK FERMENTASI PADA PETERNAK KAMBING DESA WANADADI BANJAREGARA. JURNAL PENGABDIAN KEPADA MASYARAKAT. https://doi.org/10.24114/jpkm.v25i4.14 906

Sukaryo, S., \& Purwaningrum, S. D. (2016). PEMBUATAN BIOETANOL DARI ECENG GONDOK ( Eichhornia crassipes ) DENGAN PROSES FERMENTASI. Neo Teknika. https://doi.org/10.37760/neoteknika.v2i 1.891

Utomo, B., Herawat, T., \& Prawirodigdo, S. (2010). Pertumbuhan Ternak Domba Jantan Yang Diberi Pakan Mengandung Kulit Ubi Singkong Difermentasi. Jurnal Pengkajian Dan Pengembangan Teknologi Pertanian.

Widanti, A. (2012). Produksi Protein Sel Tunggal Dari Limbah Cair Tahu dengan Kultur Saccharomyces cerevisiae 3005. Program Studi Biologi Fakultas sains dan Teknologi Universitas Sunan Kali Jaga Yogyakarta. https://doi.org/10.1007/s13398-0140173-7.2 
Widya Paramita L, Agustono, S. H. (2019). Pengaruh Penggunaan Kombucha Terhadap Kandungan Protein Kasar Dan Serat Kasar Pada Fermentasi Eceng Gondok (Eichornia crassipes) [The Effect Of Using Kombucha On Crude Protein And Crude Fiber Contents In Water Hyacinth (Eichornia crassipes) Fermentation]. Jurnal IImiah Perikanan Dan Kelautan. https://doi.org/10.20473/jipk.v2i2.1164 8

Wikandari, P., Suparmo, S., Marsono, Y., \& Rahayu, E. (2012). POTENSI BAKTERI ASAM LAKTAT YANG DIISOLASI DARI BEKASAM SEBAGAI PENGHASIL ANGIOTENSIN CONVERTING ENZYME INHIBITOR PADA FERMENTASI "BEKASAM-LIKE" PRODUCT. Agritech: Jurnal Fakultas Teknologi Pertanian UGM. https://doi.org/10.22146/agritech.9616

Wilda, N., \& Pandebesie, E. S. (2015). Hidrolisis Eceng Gondok dan Sekam Padi untuk Menghasilkan Gula Reduksi sebagai Tahap Awal Produksi Bioetanol. Jurnal Teknis Its.

Zuliyan, B., Agustono, A., \& Satyantini, W. H. (2019). PENGARUH SUBTITUSI KEDELAI DENGAN FERMENTASI TEPUNG DAUN LAMTORO PADA PAKAN UDANG VANAME (Litopenaeus vannamei) TERHADAP NILAI KECERNAAN PROTEIN DAN KECERNAAN ENERGI. Journal of Aquaculture and Fish Health. https://doi.org/10.20473/jafh.v6i3.1129 1 